Vol. 9 (2000): 105-119.

\title{
Effects of sodium sulphate and potassium chloride fertilizers on the nutritive value of timothy grown on different soils
}

\author{
Pekka Huhtanen, Seppo Ahvenjärvi and Terttu Heikkilä \\ Agricultural Research Centre of Finland, Animal Production Research, FIN-31600 Jokioinen, Finland, \\ e-mail:pekka.huhtanen@mtt.fi
}

\begin{abstract}
Third harvest samples from a pot experiment were analysed to study the effects of sodium ( $\mathrm{Na})(0$, 200 and $400 \mathrm{mg} \mathrm{dm}^{-3}$ of soil in a single application as $\left.\mathrm{Na}_{2} \mathrm{SO}_{4} \cdot 10 \mathrm{H}_{2} \mathrm{O}\right)$ and potassium $(\mathrm{K})$ application $\left(0,100\right.$ and $200 \mathrm{mg} \mathrm{dm}^{-3}$ applied at each harvest as $\left.\mathrm{KCl}\right)$ on the nutritive value of timothy grown on three different soil types (clay, loam and organogenic soil). The effects of fertilization on concentrations of crude protein, neutral detergent fibre (NDF) and non-structural carbohydrates, although statistically significant, were relatively minor in absolute terms. Na applications increased and $\mathrm{K}$ applications decreased sulphur and phosphorus concentrations, the magnitude of which was dependent on soil type. The increase in sulphur concentration can be attributed to sulphate in Na-fertilizer. The effects of fertilizers on in vitro organic matter digestibility and the potential extent of dry matter (DM) and NDF digestibility were small. Digestion kinetic parameters estimated from fermentative gas production measured using a fully automated system were used in a rumen simulation model to estimate digestibility. Total gas volume and the rate of gas production from the rapidly digestible fraction were negatively correlated with timothy $\mathrm{S}$ and $\mathrm{N}$ concentrations. Na application had no effect, but $\mathrm{K}$ application increased true rumen DM digestibility, the effect being most profound on organogenic soil. The results suggest that $\mathrm{Na}$ application does not elicit substantial positive effects on the nutritive value of timothy which has often been reported for perennial ryegrass, but K application can improve the nutritive value of timothy grown on $\mathrm{K}$ deficient soil.
\end{abstract}

Key words: digestibility, gas production, grasses, in vitro, phosphorus, rumen model, sulphur

\section{Introduction}

Diets of intensively fed ruminants are commonly supplemented with minerals in order to compensate for potential deficiencies. Increasing concentrations of certain minerals by fertiliza- tion is an alternative approach to enhance the supply of minerals from forages. A number of studies have indicated that increasing dietary concentrations of certain minerals either by fer- 


\section{AGRICULTURAL AND FOOD SCIENCE IN FINLAND}

\section{Huhtanen, P. et al. Effects of sodium and potassium application on the nutritive value of timothy}

tilization or supplementing unfertilized forages directly may have different effects on forage quality (Spears 1994). Moseley (1980) reported a higher organic matter (OM) digestibility in sheep for high rather than low sodium perennial ryegrass. The lower digestibility of low sodium grass could not be compensated for by $\mathrm{NaCl}$ supplementation in concentrate, but feed intake was reduced in this study. Milk yield was increased by Na fertilization but not by direct supplementation of NaCI in grazing cows (Chiy and Phillips 1991). When cows had a choice between Nafertilized and unfertilized pasture they preferred fertilized pasture when no direct $\mathrm{NaCl}$ supplementation was given. Furthermore, increasing the level of Na-fertilization $\left(\mathrm{NaNO}_{3}\right)$ has been shown to improve dry matter (DM) and modified acid detergent fibre digestibility in sheep (Chiy et al. 1994). These results suggest that the nutritive value of perennial ryegrass (Lolium perenne), a natrophilic plant, could be improved by Na fertilization. Timothy (Phleum pratense) and meadow fescue (Festuca pratensis), the most important forage species grown in Finland are natrophobic, such that in these species $\mathrm{Na}$ cannot be substituted for potassium (K), and therefore Na concentrations are typically low. However, in a pot experiment, Peltovuori and YliHalla (1997) demonstrated that the Na concentration in timothy could be increased up to 6.9 and $5.6 \mathrm{~g} \mathrm{~kg}^{-1} \mathrm{DM}$ on loam and organogenic soils, respectively, despite a very low marginal utilization of additional $\mathrm{Na}$. These values are considerably higher than those generally reported for timothy (Kähäri and Nissinen 1978). The objective of the present study was to investigate the effects of variation in $\mathrm{Na}$ content on the chemical composition and digestibility of timothy, using third harvest samples from the study of Peltovuori and Yli-Halla (1997). Since forage quality is primarily a function of digestibility, emphasis was placed on the determination of potential DM and neutral detergent fibre (NDF) digestibility based on in situ incubation and digestion kinetics parameters estimated from fermentative gas production.

\section{Material and methods}

Samples for the study were obtained from a pot experiment of Peltovuori and Yli-Halla (1997). The experiment was conducted as a $3 \times 3 \times 3$ factorial design with three soil types (clay, loam and organogenic soil), three levels of sodium (Na) fertilization applied as $\mathrm{Na}_{2} \mathrm{SO}_{4} \bullet 10 \mathrm{H}_{2} \mathrm{O}(0$, 200 and $400 \mathrm{mg} \mathrm{dm}^{-3}$ ) and three levels of potassium (K) applied as $\mathrm{KCl}\left(0,100\right.$ and $\left.200 \mathrm{mg} \mathrm{dm}^{-3}\right)$. Sodium was applied as a single dose at the beginning of the study, whereas $\mathrm{K}$ and nitrogen (N) were also applied for second and third harvests. Details of fertilizer application, soil composition and nutrient applications have previously been described in detail by Peltovuori and YliHalla (1997). For the present study, four of five replicates from the third harvest (108 samples) were used to investigate the effect of treatments on chemical composition and digestibility. Third harvest samples, cut after a 33 day regrowth, were selected because they showed the greatest variation in $\mathrm{Na}$ concentration.

The timothy crop was cut using scissors at a height of $2 \mathrm{~cm}$. Samples were subsequently dried at $65^{\circ} \mathrm{C}$ and analysed for $\mathrm{Ca}, \mathrm{Mg}, \mathrm{Na}$ and $\mathrm{K}$ according to Peltovuori and Yli-Halla (1997). Nitrogen $(\mathrm{N})$ was analysed by a Dumas type nitrogen analyzer (LECO FP-428, USA). Sulphur (S) and phosphorus (P) were analysed by plasma emission spectrometry following digestion of ashed samples in $\mathrm{HCl}$ and $\mathrm{HNO}_{3}$ (Luh Huang and Schulte 1985). Neutral detergent fibre was analysed according to Van Soest et al. (1991). The concentration of non-structural carbohydrates (NSC) was calculated as DM - ( ash + crude protein + ether extract + NDF) (Sniffen et al. 1992). In timothy and other temperate grasses, concentrations of pectin and starch are very low and therefore NSC is essentially comprised of water soluble carbohydrates (WSC). Ether extract concentrations were assumed to be $30 \mathrm{~g} \mathrm{~kg}^{-1} \mathrm{DM}$.

In vitro organic matter digestibility (IVOMD) and D-value ([g digestible organic matter (DOM) per $\mathrm{kg} \mathrm{DM}$ ] were determined using a cellulase based method (Friedel 1990) from samples 
Vol. 9 (2000): 105-119.

grown on loam soil (36 samples). The potential extent of DM (pDMD) and NDF digestibility (pNDFD) was determined by incubating samples in the rumen of two cows fed a grass silage-concentrate diet (55:45, on a DM basis). Samples $(4 \mathrm{~g})$ were incubated in nylon bags (pore size 6 $\mu \mathrm{m}$, open surface area $5 \%$ ) for $288 \mathrm{~h}$, washed with a household washing machine and dried at $60^{\circ} \mathrm{C}$ for $48 \mathrm{~h}$. NDF concentration was determined following bag residue extraction with NDF solution.

The rate and extent of gas production was measured using computerized gas monitoring system. One of the four replicates (27 samples) were incubated on the same day to minimize between-day variations in rumen fluid microbial activity. The system is a modification of that described by Pell and Schofield (1993). In the present system, pressure is released from the incubation bottle by a magnetic valve during fermentation when the pressure exceeds 28 mbar, whereas in the system of Pell and Schofield (1993) gas is accumulated in fermentation bottles. Samples $(500 \mathrm{mg}$ ) were incubated in serum bottles $(100 \mathrm{ml})$ containing $60 \mathrm{ml}$ phosphate-bicarbonate buffer (Goering and Van Soest 1970) and $20 \mathrm{ml}$ diluted rumen fluid (rumen fluid:buffer 2:1). Rumen fluid was taken from two heifers fed a grass silage diet. Measurements of gas production were recorded every $15 \mathrm{~min}$ for $72 \mathrm{~h}$.

Gas curves were fitted to a dual-pool Gompertz equation.

$$
\begin{aligned}
V= & V_{1} \exp \left[-\exp \left(1+k_{1}\left(\lambda_{1}-t\right)\right)\right]+ \\
& V_{2} \exp \left[-\exp \left(1+k_{2}\left(\lambda_{2}-t\right)\right)\right]
\end{aligned}
$$

where $V=$ volume of gas produced at time $t$, $V_{1}$ and $V_{2}$ are maximum gas volumes produced from complete digestion of each pool at time $t=$ $\infty, k_{1}$ and $k_{2}$ are rate constants called specific rates (= maximum rate/maximum volume), and $\lambda_{1}$ and $\lambda_{2}$ are integration constants equivalent to the lag term. The derived equation provided an excellent fit of experimental data (mean of mean square errors $0.42 \pm 0.04 ; n=100 ; R^{2}>0$. 9999). Curve-fitting was carried out using the non-linear procedure of SAS (1985) using an iterative
Marquardt method.

Ruminal digestibility of potentially digestible DM (RDPDM) was estimated using a mathematical modelling approach. A two-compartmental model with selective retention of particles in the rumen (Allen and Mertens 1988) was used for both fast $\left(V_{1}\right)$ and slow $\left(V_{2}\right)$ pools (Fig. 1). Material disappears from the first compartment (non-escapable pool; NE-pool) either by digestion $\left(k_{d}\right)$ or release $\left(k_{r}\right)$ to the second compartment (escapable pool; E-pool). From the escapable pool, material disappears either by digestion or passage to the lower tract $\left(k_{p}\right)$. The $k_{r}$ is time-dependent (Pond et al. 1988), i.e. the probability of particles to release from the NEpool to E-pool or to escape from the system increases with rumen residence. Values of 20 and $30 \mathrm{~h}$ derived from cattle fed $80 \mathrm{~g} \mathrm{DM} \mathrm{kg}^{-0.75}$ live weight (Huhtanen and Kukkonen 1995) were used as mean retention time (MRT) for NE- and E-pools, respectively. A model with third degree of gamma time-dependency in the first compartment has generally resulted in the best fit of duodenal or faecal marker concentrations in our studies. In the model, $k_{r}$ is a derivative of material remaining in the $\mathrm{NE}$-pool at time $=t$.

$k_{r}=\left(0.5 \lambda^{3}+t^{2}\right) \times\left(1+\lambda \times t+0.5(\lambda \times t)^{2}\right)^{-1}$

where $\lambda$ is $3 /$ MRT (i.e. $3 / 20=0.15$ ) and $t$ is time.

Rate constants of gas production from the fast and slow pool $\left(k_{d 1}\right.$ and $\left.k_{d 2}\right)$ at time $=\mathrm{t}$ were calculated as partial derivatives of pool size divided by the remaining pool size.

$$
\begin{aligned}
k_{d 1}= & \exp \times k_{1} \times \exp \left(1+k_{1} \lambda \exp \times\right. \\
& \left.\left(\lambda_{1}-t\right)\right) \times\left[\operatorname { e x p } \left(\operatorname { e x p } \left(1+k_{1} \times \exp \times\right.\right.\right. \\
& \left.\left.\left.\left(\lambda_{1}-t\right)\right)\right)\right]^{-1} \\
k_{d 2}= & \exp \times k_{2} \times \exp \left(1+k_{2} \times \exp \times\right. \\
& \left.\left(\lambda_{2}-t\right)\right) \times[\exp (\exp \\
& \left.\left.\left.\left(1+k_{2} \times \exp \times \lambda_{2}-t\right)\right)\right)\right]^{-1}
\end{aligned}
$$

where $k_{1}$ and $k_{2}$ are rate constants and $\lambda_{1}$ and $\lambda_{2}$ are lag parameters of gas production from the fast and slow pool. Similar passage kinetics parameters were assumed for fast and slow digestion pools. Simulations were made using 
Huhtanen, P. et al. Effects of sodium and potassium application on the nutritive value of timothy

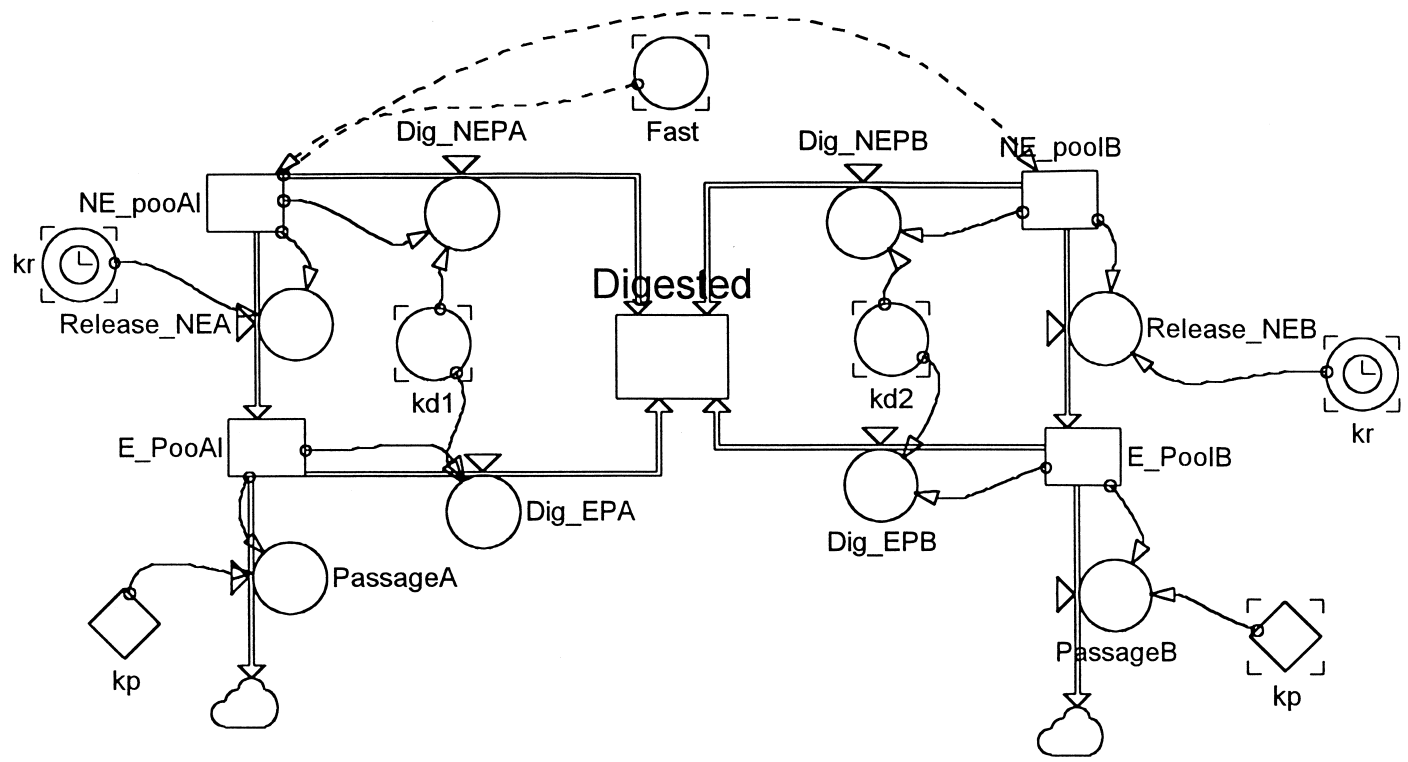

Fig. 1. Rumen simulation model for estimation digestibility of potentially digestible DM. NE-pool = non-escapable pool, $\mathrm{E}=$ escapable pool, Fast $=$ proportion of fast pool of total gas production, A refers to fast pool and B to slow pool. Rate parameters are explained in Material and methods.

POWERSIM $^{\circledR}$ (Isdalst $\varnothing$, Norway) software, adopting a simulation step of $0.0625 \mathrm{~h}$.

True ruminal DM digestibility (TRDMD) was calculated as follows:

$$
\text { TRDMD }=\text { RDPDM } \times \text { pDMD }
$$

Data concerning the chemical composition and in situ disappearance of feeds were subjected to statistical analysis according to the following model:

$$
\begin{aligned}
\mathrm{Y}_{\mathrm{ijkl}}= & \mathrm{Na}_{\mathrm{i}}+\mathrm{K}_{\mathrm{j}}+\mathrm{S}_{\mathrm{k}}+(\mathrm{NaK})_{\mathrm{ij}}+(\mathrm{NaS})_{\mathrm{ik}}+(\mathrm{KS})_{\mathrm{jk}} \\
& +(\mathrm{NaKS})_{\mathrm{ijk}}+\mathrm{e}_{\mathrm{ijkl}},
\end{aligned}
$$

where $\mathrm{Na}, \mathrm{K}$ and $\mathrm{S}$ are the effects of $\mathrm{Na}, \mathrm{K}$ and soil and their interactions, respectively. For gas production and modelling data, incubation run (replicate) was also included in the model, because differences in the activity of microbial inoculum resulted in significant differences between runs. The effects of $\mathrm{Na}$ and $\mathrm{K}$ fertilization were further separated into linear and quadratic effects using orthogonal polynomial contrasts.

\section{Results}

The effects of fertilization and soil type on mineral concentrations of third-cut timothy grass are shown in Table 1. Complete data on $\mathrm{Na}, \mathrm{K}, \mathrm{Ca}$ and $\mathrm{Mg}$ concentrations have previously been reported (Peltovuori and Yli-Halla 1997). With third-cut grass, increased applications of $\mathrm{Na}$ linearly increased $(\mathrm{P}<0.001)$ timothy $\mathrm{Na}$ concentration, the effect decreasing (interaction $\mathrm{P}<0.001)$ with the level of $\mathrm{K}$ fertilization. Increases in Na concentration were greater for timothy grown on loam $\left(+3.7 \mathrm{~g} \mathrm{~kg}^{-1} \mathrm{DM}\right)$ than organogenic $\left(+2.3 \mathrm{~g} \mathrm{~kg}^{-1}\right)$ or clay $\left(+1.5 \mathrm{~g} \mathrm{~kg}^{-1}\right)$ soils. $\mathrm{Na}$ application had only marginal, but statistically significant quadratic effects $(\mathrm{P}<0.01)$ on timothy $\mathrm{K}$ concentration. $\mathrm{K}$ concentration was markedly higher in timothy grown on clay (38.2 $\left.\mathrm{g} \mathrm{kg}^{-1} \mathrm{DM}\right)$ than on loam $\left(31.9 \mathrm{~g} \mathrm{~kg}^{-1}\right)$ or organogenic (29.1 $\left.\mathrm{g} \mathrm{kg}^{-1}\right)$ soils. Ca concentrations decreased with increases in both $\mathrm{Na}$ and $\mathrm{K}$ 
Vol. 9 (2000): 105-119.
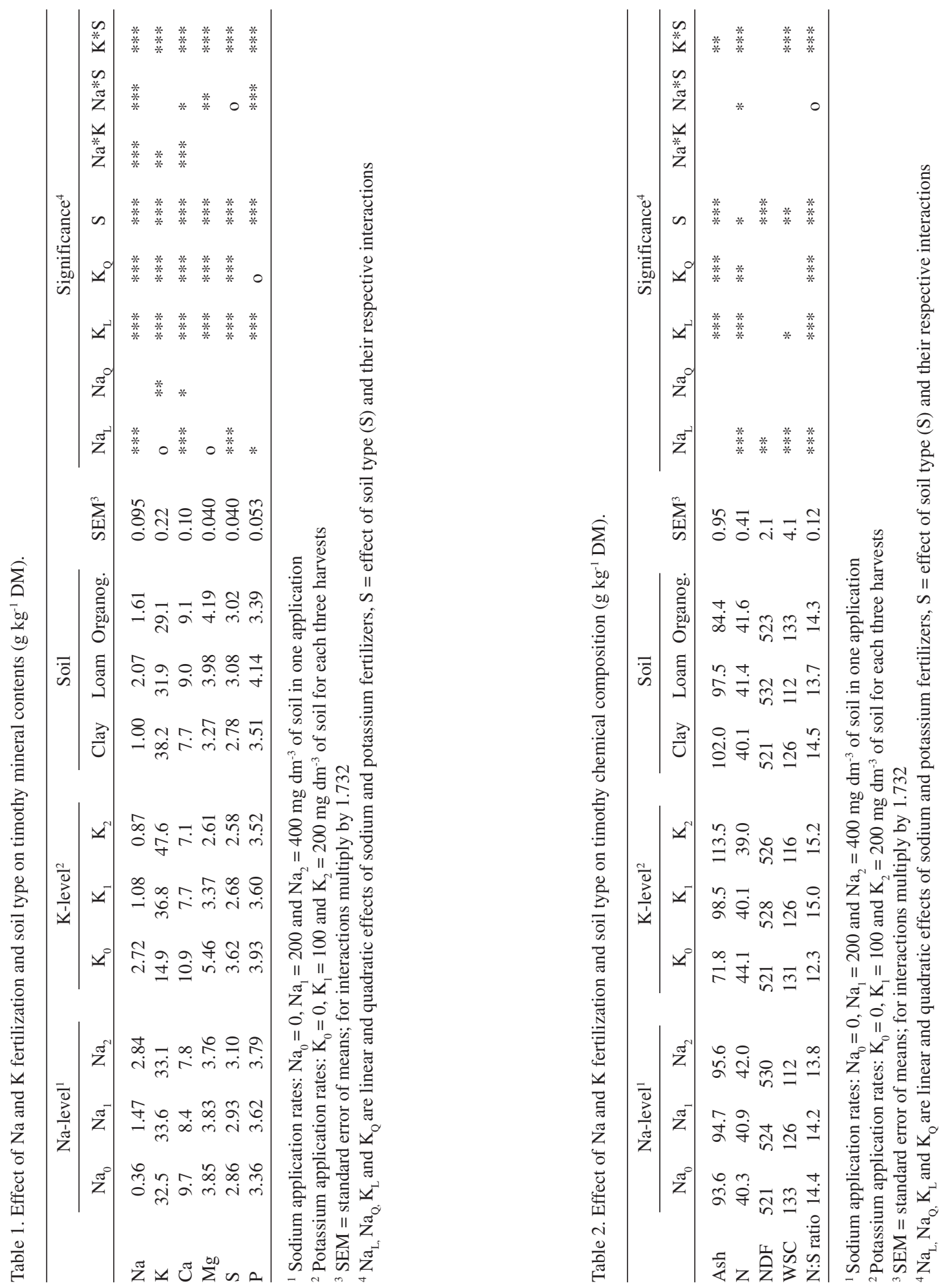


\section{AGRICULTURAL AND FOOD SCIENCE IN FINLAND}

\section{Huhtanen, P. et al. Effects of sodium and potassium application on the nutritive value of timothy}

fertilization. Mg concentration decreased $(\mathrm{P}<0.001)$ with $\mathrm{K}$ fertilization.

Sulphur concentration increased linearly $(\mathrm{P}<0.001)$ with $\mathrm{Na}$ fertilization because $\mathrm{Na}$ was applied as sulphate, and decreased $(\mathrm{P}<0.001)$ with $\mathrm{K}$ fertilization, the effect being greater between $\mathrm{K}_{0}$ and $\mathrm{K}_{1}$ than between $\mathrm{K}_{1}$ and $\mathrm{K}_{2}$ (quadratic effect $\mathrm{P}<0.001)$. Grasses grown on clay contained less $\mathrm{S}$ than those grown on other soils. There was a significant interaction $(\mathrm{P}<0.001)$ between $\mathrm{K}$ application level and soil type in $\mathrm{S}$ content, the decrease being much greater on organogenic soil (-1.8 $\left.\mathrm{g} \mathrm{kg}^{-1} \mathrm{DM}\right)$ than on loam $\left(-0.8 \mathrm{~g} \mathrm{~kg}^{-1}\right)$ or clay $\left(-0.5 \mathrm{~g} \mathrm{~kg}^{-1}\right)$ soils.

$\mathrm{Na}$ fertilization increased $(\mathrm{P}<0.05)$ and $\mathrm{K}$ fertilization decreased $(\mathrm{P}<0.001) \mathrm{P}$ concentration in timothy. The effect of $\mathrm{K}$ was again more profound on organogenic soil than on other soil types (interaction $\mathrm{P}<0.001$ ).

The effects of treatments on chemical composition of timothy are shown in Table 2. Ash concentration increased with the level of $\mathrm{K}$ fertilization that generally reflected increases in $\mathrm{K}$ content. Grass grown on mineral soils contained more ash than that grown on organogenic soil. Increasing the level of $\mathrm{Na}$ fertilization increased $\mathrm{N}$ concentration from 40.3 to $42.0 \mathrm{~g} \mathrm{~kg}^{-1} \mathrm{DM}$ $(\mathrm{P}<0.001)$, whereas $\mathrm{K}$ application decreased $\mathrm{N}$ $\left(\mathrm{P}_{\text {Lin }}<0.001, \mathrm{P}_{\text {Quadr }}<0.01\right)$. The effect of $\mathrm{K}$ on $\mathrm{N}$ concentration was much greater on organogenic (-10.7 $\left.\mathrm{g} \mathrm{kg}^{-1} \mathrm{DM}\right)$ than on clay $\left(-1.8 \mathrm{~g} \mathrm{~kg}^{-1}\right)$ or loam $\left(-2.5 \mathrm{~g} \mathrm{~kg}^{-1}\right)$ soils. NDF concentration increased and WSC decreased linearly $(\mathrm{P}<0.001)$ with the level of $\mathrm{Na}$ fertilization. Increasing $\mathrm{K}$ application increased the concentration of WSC in timothy grown on organogenic soil $\left(+15 \mathrm{~g} \mathrm{~kg}^{-1}\right.$ DM), but decreased that grown on clay $\left(-39 \mathrm{~g} \mathrm{~kg}^{-1}\right)$ and loam $\left(-33 \mathrm{~g} \mathrm{~kg}^{-1}\right)$ soils.

$\mathrm{Na}$ application had no effects on kinetic parameters of in vitro gas production (Table 3 ). Increasing $\mathrm{K}$ application increased the rate of gas production from the fast pool (linear effect $\mathrm{P}<0.01)$ and tended $(\mathrm{P}=0.08)$ to decrease lag time $(\mathrm{P}<0.05)$. Increasing $\mathrm{K}$ fertilization only decreased lag time of the fast pool for timothy grown on organogenic soil (from 1.9 to $1.0 \mathrm{~h}$ ), whereas the effects on clay and loam were rela- tively small and inconsistent. The rate of gas production from the slow pool was slower $(\mathrm{P}<0.01)$ for timothy grown on clay than that grown on other soils. In contrast, gas production from the slow pool and total gas volume were highest for timothy grown on clay. Differences in total gas volume were much greater when no K fertilizer was applied (134, 122 and $113 \mathrm{ml}$ for clay, loam and organogenic soil, respectively) than at medium $(130,124,121 \mathrm{ml}$ respectively) or high levels of $\mathrm{K}$ fertilization (128,120,126 ml, respectively).

Differences between in vitro OM digestibility of timothy grown on loam were small in absolute terms, but were in many cases statistically significant (Table 4). Na fertilization tended to improve and $\mathrm{K}$ fertilization to decrease in vitro OMD. Increased $\mathrm{K}$ fertilization clearly decreased D-value, but most of the differences can be attributed to increased ash concentrations. Differences in the potential extent of DM and NDF digestion were small, but statistically significant. As a result of the increased rate of digestion and reduced lag of the fast pool, the proportion of potentially digestible DM truly digested in the rumen increased $(\mathrm{P}<0.05)$ with $\mathrm{K}$ fertilizer application. Since pDMD marginally improved, true rumen DM digestibility increased $(\mathrm{P}<0.01)$ with $\mathrm{K}$ application. Differences in the rate of digestion of the slow pool and the greater proportion of the fast pool contributing to total gas production resulted in significant $(\mathrm{P}<0.001)$ differences in RDPDM and TRDMD between soil types, the values being highest with organogenic soil and lowest with clay. The effects of $\mathrm{Na}$ and $\mathrm{K}$ fertilization on TRDMD tended to vary between different soil types (Fig. 2). On clay and loam the effects of fertilization were rather small and inconsistent, but for organogenic soil Na improved TRDMD when no K fertilization was applied and the reverse was true when $\mathrm{K}$ was applied.

Correlation coefficients between digestion parameters and mineral and $\mathrm{N}$ concentrations in herbage are shown in Table 5. Total gas volume was negatively correlated with the concentrations of $\mathrm{N}, \mathrm{S}, \mathrm{Na}, \mathrm{Ca}, \mathrm{Mg}$ and $\mathrm{P}$. The rate of di- 
Vol. 9 (2000): 105-119.

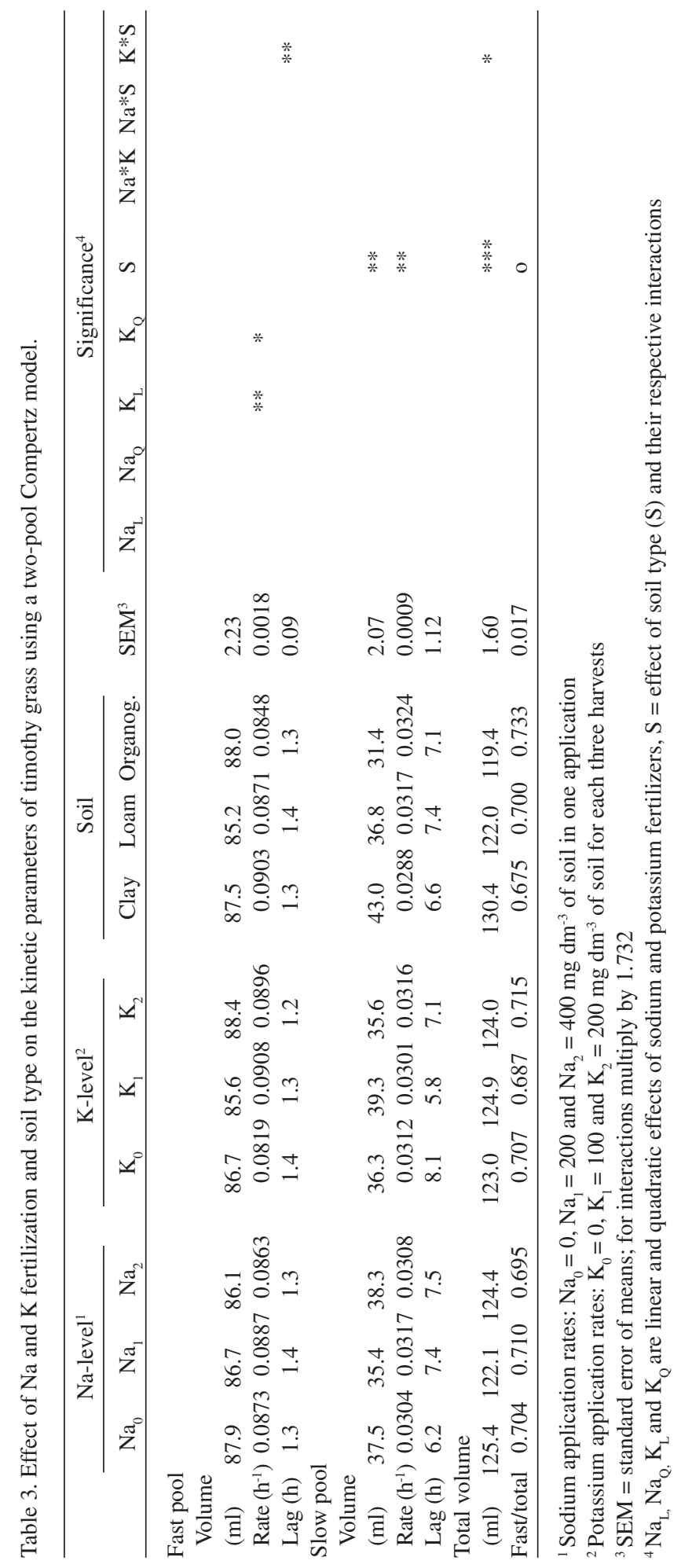


Huhtanen, $P$. et al. Effects of sodium and potassium application on the nutritive value of timothy

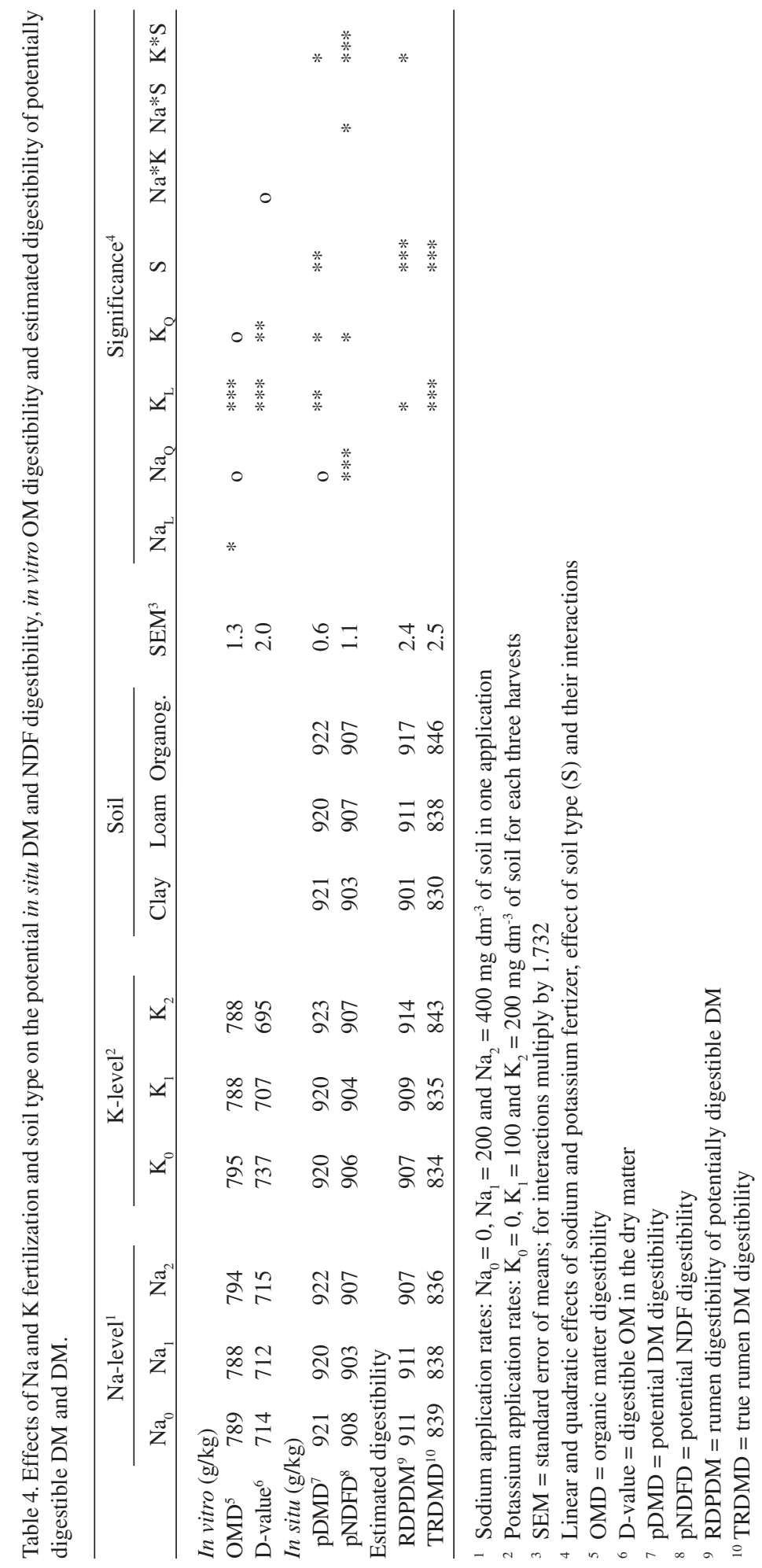


Vol. 9 (2000): 105-119.

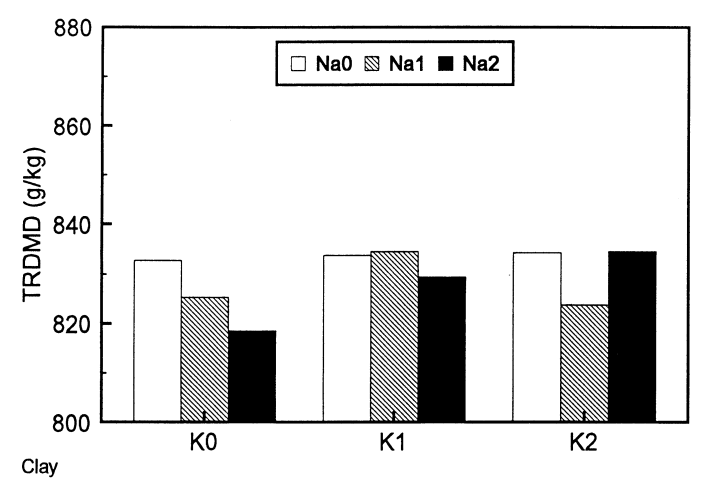

Fig. 2. The effects of $\mathrm{Na}$ and $\mathrm{K}$ fertilization on true rumen dry matter digestibility (TRDMD) of timothy grown on different soils. Sodium application rates: $\mathrm{Na}_{0}=0, \mathrm{Na}_{1}=$ 200 and $\mathrm{Na}_{2}=400 \mathrm{mg} \mathrm{dm}^{-3}$ of soil in one application ${ }^{2}$; Potassium application rates: $\mathrm{K}_{0}=0, \mathrm{~K}_{1}=100$ and $\mathrm{K}_{2}=$ $200 \mathrm{mg} \mathrm{dm}^{-3}$ of soil for each three harvests.

gestion of the fast pool was negatively $(\mathrm{P}<0.001)$ correlated with $\mathrm{N}, \mathrm{S}, \mathrm{Ca}$ and $\mathrm{Mg}$ and positively $(\mathrm{P}<0.001)$ correlated with K. Mineral concentrations had no significant relationship with the rate of gas production from the slow pool, only
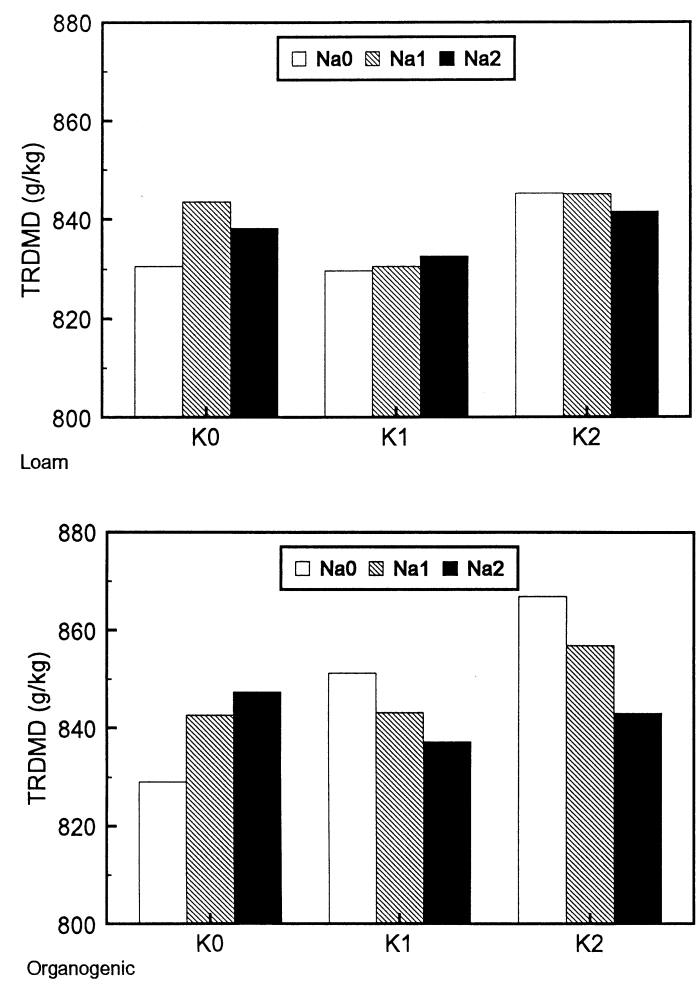

Na tended $(\mathrm{P}=0.07)$ to increase $k_{d 2}$. The lag parameter of the fast pool increased (at least $\mathrm{P}<0.05$ ) with increasing mineral (except $\mathrm{K}$ ) and $\mathrm{N}$ concentrations. In situ pDMD and pNDFD were not strongly correlated with mineral con-

Tab1e 5. Correlation coefficients between chemical composition and digestion parameters $(\mathrm{n}=108)$.

\begin{tabular}{|c|c|c|c|c|c|c|c|}
\hline & $\mathrm{N}$ & $\mathrm{Na}$ & $\mathrm{K}$ & $\mathrm{Ca}$ & $\mathrm{Mg}$ & $\mathrm{P}$ & $\mathrm{S}$ \\
\hline Gas volume & $-0.57^{* *}$ & $-0.48^{*}$ & 0.28 & $-0.38^{*}$ & $-0.40^{*}$ & $-0.27^{*}$ & $-0.45^{*}$ \\
\hline Rate (fast) & $-0.64^{* * *}$ & -0.30 & $0.69^{* * * *}$ & $-0.72^{* * * *}$ & $-0.73^{* * * *}$ & $-0.38^{*}$ & $-0.71^{\text {*** }}$ \\
\hline Rate (slow) & 0.09 & $0.35^{\circ}$ & -0.10 & -0.04 & 0.12 & -0.04 & 0.07 \\
\hline Lag (fast) & $0.71^{* * * *}$ & $0.51^{* *}$ & $-0.37^{\circ}$ & $0.47^{*}$ & $0.47^{*}$ & $0.50^{* *}$ & $0.61^{* * *}$ \\
\hline Lag (slow) & 0.15 & 0.29 & -0.21 & 0.04 & 0.19 & 0.08 & 0.18 \\
\hline In situ $\mathrm{pDMD}$ & 0.02 & -0.08 & 0.25 & -0.05 & -0.19 & -0.22 & -0.06 \\
\hline In situ $\mathrm{pNDFD}$ & $0.38^{*}$ & 0.13 & -0.12 & $0.36^{\circ}$ & 0.20 & $0.36^{\circ}$ & 0.31 \\
\hline $\mathrm{RDPDM}^{1}$ & -0.19 & 0.06 & 0.13 & -0.18 & -0.11 & -0.29 & -0.22 \\
\hline TRDMD $^{2}$ & -0.20 & 0.05 & 0.17 & -0.16 & -0.13 & -0.32 & -0.20 \\
\hline
\end{tabular}

Significance of correlations: ${ }^{\circ}(\mathrm{P}<0.10),{ }^{*}(\mathrm{P}<0.05),{ }^{* *}(\mathrm{P}<0.01),{ }^{* * *}(\mathrm{P}<0.001)$

${ }^{1} \mathrm{RDPDM}=$ rumen digestibility of potentially digestible $\mathrm{DM}$

${ }^{2} \mathrm{TRDMD}=$ true rumen DM digestibility 


\section{AGRICULTURAL AND FOOD SCIENCE IN FINLAND}

\section{Huhtanen, P. et al. Effects of sodium and potassium application on the nutritive value of timothy}

centrations. Neither estimated ruminal digestibility of potentially digestible DM nor true ruminal digestibility were significantly correlated with mineral concentrations.

\section{Discussion}

The present study was designed to investigate the effects of $\mathrm{Na}$ and $\mathrm{K}$ fertilizers on nutritive value of timothy. Na was applied as sulphate and $\mathrm{K}$ as chloride, and therefore potential effects of anions can not be eliminated from those effects attributed to cations. Sodium sulphate fertilization increased the Na concentration of timothy considerably, despite timothy being considered to be a natrophobic species (Chiy and Phillips 1995). Poor utilization of additional Na provided further evidence to indicate the natrophobic nature of timothy (Peltovuori and Yli-Halla 1997). In the current study $\mathrm{N}$ concentration was increased by $\mathrm{Na}$ application as indicated by the close correlation between timothy $\mathrm{N}$ and $\mathrm{Na}$ concentrations $(r=0.71 ; \mathrm{P}<0.001 ; n=108)$. In contrast, Chiy and Phillips (1993) reported that under field conditions increases in $\mathrm{Na}$ fertilizer reduced $\mathrm{N}$ concentration in perennial ryegrass, primarily due to decreases in non-protein $\mathrm{N}$. They also reported improved recoveries of applied $\mathrm{N}$ with $\mathrm{Na}$ fertilization due to increased $\mathrm{DM}$ yield. Increasing the rate of $\mathrm{K}$ application decreased $\mathrm{N}$ concentration in timothy, especially that grown on organogenic soil. K deficiency limited growth under these circumstances leading to an accumulation of $\mathrm{N}$ in the plant. On organogenic soil DM yield in the third harvest without $\mathrm{K}$ was only $66 \%$ of that with $\mathrm{K}$ fertilization (Peltovuori and Yli-Halla 1997). The mean $\mathrm{N}$ concentration was very high $\left(41.0 \mathrm{~g} \mathrm{~kg}^{-1}\right.$ $\mathrm{DM})$ which can be attributed to very high levels of $\mathrm{N}$ fertilization ( $900 \mathrm{~kg} \mathrm{ha}^{-1}$ ) and the relatively early stage of maturity at harvest (33 day regrowth period). The NPN content was not measured in the present study, but high timothy $\mathrm{N}$ concentrations suggest that NPN concentra- tions were also high, particularly in samples with increased $\mathrm{N}$ concentrations (organogenic soil without $\mathrm{K}$ application).

The effects of Na fertilization on herbage cell wall concentrations have been variable. In the present study and those of Chiy et al. (1993, 1994) and Chiy and Phillips (1996), concentrations of cell wall constituents were marginally, but significantly increased with $\mathrm{Na}$ fertilization, whereas Chiy and Phillips (1998) and Cushnahan et al. (1996) reported no effects. Chiy et al. (1994) attributed a higher modified acid detergent fibre (MADF) concentration with $\mathrm{Na}$ fertilization to increased herbage growth rates enabling maturity to be attained faster. However, this suggestion is inconsistent with an improved digestibility of Na fertilized grass (Moseley 1980, Chiy et al. 1994).

In the current study increasing $\mathrm{Na}$ application decreased WSC in grass, a finding inconsistent with that of Chiy and Phillips (1993, 1998). Low WSC concentration in timothy grown on organogenic soil without $\mathrm{K}$ application may be related to a severe $\mathrm{K}$ deficiency and consequently reduced growth rates.

The effects of $\mathrm{Na}$ fertilization on herbage $\mathrm{S}$ content appear to depend on the type of Na fertilizer used. Increases in herbage $S$ content were observed in the present study when sodium was applied as $\mathrm{Na}_{2} \mathrm{SO}_{4}$, whereas no changes (Chiy and Phillips 1993) or even a decrease (Chiy et al. 1994) were observed when $\mathrm{Na}$ was applied as nitrate. The high correlation between herbage $\mathrm{Na}$ and $\mathrm{S}$ concentrations $(\mathrm{r}=0.684 ; \mathrm{P}<0.001$; $\mathrm{n}=108$ ) suggest that increases in $\mathrm{S}$ concentrations were derived from $\mathrm{Na}$ fertilizer applied as $\mathrm{Na}_{2} \mathrm{SO}_{4}$. Sulphur applications supplied as sulphate have generally increased herbage $\mathrm{S}$ concentrations (Spears 1994, Chiy and Phillips 1998). Sulphur is also prerequisite for metabolism and growth of rumen microorganisms (Durand and Komisarczuk 1988). Increasing dietary S content by supplementation or fertilization has generally elicited positive digestibility and animal performance responses when the S content of unsupplemented diets has been low (Spears 1994). In the present study the herbage N:S ra- 
Vol. 9 (2000): 105-119.

tio of 14.3 was below $15: 1$, above which the likelihood of S deficiency increases (Dijkshoorn and van Wijk 1967). In all $\mathrm{Na} \times \mathrm{K} \times$ Soil combinations the herbage $\mathrm{S}$ content exceeded critical values of $2.0 \mathrm{~g} \mathrm{~kg}^{-1} \mathrm{DM}$ for ryegrass swards (Jones et al. 1972). However, in timothy grown on organogenic soil without $\mathrm{K}$ application S concentration exceeded $4 \mathrm{~g} \mathrm{~kg}^{-1} \mathrm{DM}$, which may have adverse effects due to a high sulphate content. The increased herbage $S$ content in response to $\mathrm{S}$ fertilization can largely be accounted for by increased sulphate S (Spears et al. 1985, Chiy and Phillips 1998). In grazing cows application of sulphur fertilizer can have adverse effects on milk yield and milk fat content (Chiy et al.1999). In the present study the high S content in herbage grown on loam or organogenic soil without $\mathrm{K}$ fertilization ( 3.6 and $4.2 \mathrm{~g} \mathrm{~kg}^{-1}$ ) suggest that factors other than supply directly from fertilizers may also influence forage $S$ concentration. Increasing the rate of $\mathrm{Na}$-sulphite fertilization in pots without $\mathrm{K}$ application decreased $\mathrm{S}$ concentration from 4.3 to $3.9 \mathrm{~g} \mathrm{~kg}^{-1}$ on organogenic soil, whereas on loam soils corresponding fertilizer application rates increased $\mathrm{S}$ content from 3.2 to $4.1 \mathrm{~g} \mathrm{~kg}^{-1}$. Severe $\mathrm{K}$ deficiency as indicated by a low $\mathrm{K}$ content in herbage $\left(8.7 \mathrm{~g} \mathrm{~kg}^{-1} \mathrm{DM}\right)$ on organogenic soil in unfertilized pots was probably associated with an excessive $S$ uptake (4.4 $\left.\mathrm{g} \mathrm{kg}^{-1}\right)$.

In vitro $\mathrm{OM}$ digestibility of grass grown on loam was not markedly influenced either by $\mathrm{Na}$ or K application but D-value decreased with increased $\mathrm{K}$ application due to increased ash content. It is likely that the effect of lower D-value on feed intake is different from that generally observed with delayed harvest (Huhtanen 1993). Consistently with the observations from the current in vitro study, only minor effects of fertilization were demonstrated on potential extent of digestion determined using in situ method. In other studies $\mathrm{Na}$ fertilization has improved in vivo digestibility of perennial ryegrass in sheep (Moseley 1980, Chiy et al. 1994) and grazing cows (Cushnahan et al. 1996). Similar effects also have been observed in in vitro studies (Chiy and Phillips 1991, 1993, 1998, Chiy et al. 1998).
Improved digestibility with $\mathrm{Na}$ application has been attributed to increased herbage WSC content (Chiy and Phillips 1993) and to increased rumen $\mathrm{pH}$ (Chiy et al. 1993). The increased proportion of live herbage mass may also explain the improvements in digestibility (Chiy and Phillips 1991). Discrepancies between current data and published observations may result from the use of different forage species (timothy vs. perennial ryegrass). However, a considerable range in herbage Na content $\left(0.16-7.13 \mathrm{~g} \mathrm{~kg}^{-1} \mathrm{DM}\right)$ was obtained despite timothy being a natrophobic species. The concentrations of non-structural carbohydrates was not increased by $\mathrm{Na}$ application, an effect often observed with perennial ryegrass. In the pot experiment the effects of fertilization on live herbage mass may potentially be smaller than under field conditions masking potential effects on digestibility. If positive effects of $\mathrm{Na}$ fertilization were only associated with improved rumen environment, then in vitro or in situ methods are inappropriate to detect such differences. However, increased in vitro digestibility in the studies of Chiy and Phillips (1991, 1993 and 1998) suggests that intrinsic characteristics of herbage are also modified by $\mathrm{Na}$ fertilization. Furthermore, small increases in $\mathrm{Na}$ supply from fertilized grass are not likely to cause such changes in rumen $\mathrm{pH}$ in sheep fed at maintenance level, which would improve forage digestibility. Data of Moseley (1980) and Chiy and Phillips (1991) also suggest that improvements in nutritive value of $\mathrm{Na}$ fertilized grass were not only related to increased $\mathrm{Na}$ supply, since direct $\mathrm{Na}$ supplementation did not improve digestibility or milk production.

There were marked differences in the total gas volume produced from timothy grown on different soil types despite having similar potential digestibility. This may result from differences in rumen fermentation pattern, since propionate production liberates less gas than acetate or butyrate (Hungate 1966), changes in the efficiency of microbial protein synthesis (Blümmel et al. 1997) or from differences in crude protein content (Cone and van Gelder 1999). In the present study gas production was decreased by 


\section{AGRICULTURAL AND FOOD SCIENCE IN FINLAND}

\section{Huhtanen, P. et al. Effects of sodium and potassium application on the nutritive value of timothy}

$4.24 \mathrm{ml} \mathrm{g}^{-1} \mathrm{DM}$ per $10 \mathrm{~g} \mathrm{~kg}^{-1}$ increase in crude protein content $(\mathrm{r}=0.57)$. This value is greater than $2.48 \mathrm{ml} \mathrm{g}^{-1}$ organic matter reported by Cone and van Gelder (1999). In the current study, a very high level of $\mathrm{N}$ fertilization was used which resulted in increased timothy $\mathrm{N}$ content, possibly as nitrate $\mathrm{N}$. Nitrogen is in a much more reduced form in proteins than in nitrate, and therefore nitrate $\mathrm{N}$ may decrease gas production more than protein N. Sulphur content was positively correlated with $\mathrm{N}$ concentrations $(r=0.95)$, but the relationship $\left[\mathrm{S}\left(\mathrm{g} \mathrm{kg}^{-1}\right)=-4.15+0.173 \mathrm{~N}\right.$ $\left(\mathrm{g} \mathrm{kg}^{-1}\right)$ ] suggests that increases in $\mathrm{S}$ were greater than requirements for protein synthesis and must be contained in the inorganic fraction, mainly as sulphate. Sulphate acts as a hydrogen acceptor in the rumen which could also explain reduced gas production from timothy grown on organogenic soil without K application. The negative correlation of some minerals ( $\mathrm{Na}, \mathrm{Ca}, \mathrm{Mg}$ and $\mathrm{P}$ ) with total gas volume is probably due to mutual correlations with $\mathrm{N}$ and $\mathrm{S}$, rather than indicative of causative factors.

Although the rate of gas production and lag time for the fast pool $\left(k_{d l}\right.$ and $\left.\lambda_{1}\right)$ were closely correlated with mineral concentrations, the relationships between mineral concentrations and estimated digestibility of potentially digestible DM in the rumen (RDPDMD) and TRDMD were poor. Variation in $k_{d l}$ had only minor effects on RDPMD and TRDMD ( $\mathrm{r}=0.16$ and -0.09$)$ because the rate of digestion was very fast in relation to passage rate, and very little material from this pool can escape fermentation. However, the rate of digestion in the slow pool $\left(k_{d 2}\right)$ was highly correlated with RDPDM and TRDMD ( $r=0.82$ and 0.77 ), but was not significantly influenced by the mineral composition of timothy. The results from the rumen simulation model suggest that differences in the rate of digestion of rapidly degradable fraction have only minor effects on total digestibility, whereas the rate of digestion of the slowly digestible fraction and potential digestibility are of much greater importance. Sodium had a positive effect on TRDMD only when grass was grown on organogenic soil without K application (Fig. 2). Under these circum- stances Na could probably alleviate the deficiency of K. The proportion of live herbage mass was not measured in the present study, but it is possible that proportion of dead material was increased on $\mathrm{K}$ deficient soil. The increase in timothy WSC concentration grown on organogenic soil with $\mathrm{K}$ application tend to support this suggestion. In studies with perennial ryegrass, $\mathrm{Na}$ fertilization has increased the proportion of live herbage mass (Chiy and Phillips 1991, 1998).

Estimated TRDMD was on average $838 \mathrm{~g} \mathrm{~kg}^{-1}$. Digestibility of organic matter in early cut grass is generally $30 \mathrm{~g} \mathrm{~kg}^{-1}$ higher than DM digestibility, while faecal output of metabolic OM is approximately $90 \mathrm{~kg}^{-1} \mathrm{DM}$ intake in sheep fed at maintenance level (Rinne et al. unpublished). Taking these factors into account, and that digestion of material primarily not fermented in the rumen (lipids) and passage kinetics parameters were derived from a higher feeding level, OM digestibility estimated from the simulations approached $800 \mathrm{~g} \mathrm{~kg}^{-1}$, a value consistent with that of early-cut grasses measured in vivo and in vitro OMD determined using a cellulase based method.

\section{Conclusions}

The present results showed that $\mathrm{Na}$ and $\mathrm{K}$ fertilization and soil type influence mineral concentrations in timothy. However, in relation to the amount of $\mathrm{Na}$ applied, changes in mineral concentrations were relatively small. Differences in the concentrations of N, NDF, NSC were also relatively small in absolute terms, but were often statistically significant. The effects of fertilization on in vitro OM digestibility and the potential extent of DM and NDF digestibility were small, and probably have only minor effects on the nutritive value of timothy in practice. Total gas volume and rate of gas production from the rapidly digestible pool were significantly correlated with mineral and $\mathrm{N}$ concen- 
Vol. 9 (2000): 105-119.

trations in timothy. $\mathrm{Na}$ fertilization improved estimated true rumen DM digestibility only for timothy grown on organogenic soil suffering from severe $\mathrm{K}$ deficiency. It appears that $\mathrm{K}$ deficiency has adverse effects both on herbage yield and quality. The current data from a pot experiment suggest that $\mathrm{Na}$ fertilization does not have positive effects on the digestibility of timothy, a natrophopic species, that have often been report- ed in field studies conducted with natrophilic perennial ryegrass.

Acknowledgements. The authors are grateful to Dr. Markku Yli-Halla and Mr. Tommi Peltovuori, MSc., for providing samples for determination of nutritive value, Dr. Markku Yli-Halla in particular, for useful suggestions and comments. Financial support from Kemira Agro, Ltd. is greatly appreciated. We would also like to express our gratitude to laboratory staff and metabolism unit personnel.

\section{References}

Allen, M.S. \& Mertens, D.R. 1988. Evaluating constraints of fiber digestion by rumen microbes. Journal of $\mathrm{Nu}$ trition 118: 261-270.

Blümmel, M., Steingaß, H. \& Becker, K. 1997. The relationship between in vitro gas production, in vitro microbial biomass yield and $15 \mathrm{~N}$ incorporation and its implications for the prediction of voluntary feed intake of roughages. British Journal of Nutrition 77: 911-921.

Chiy, P.C., Abdul-latif, A.A., Hassan, M.H. \& \& Phillips, C.J.C. 1998. Effects of sodium and potassium fertilisers on the composition of herbage and its acceptability to dairy cows. Journal of Food Science and Agriculture 76: 289-297.

- , Avezinius, J.A. \& Phillips, C.J.C. 1999. Sodium fertilizer application to pasture. 9. Effects of combined or separate applications of sodium and sulphur fertilizers on herbage composition and dairy cow production. Grass and Forage Science 54: 312-321.

- \& Phillips, C.J.C. 1991. The effects of sodium chloride application to pasture, or its direct supplementation, on dairy cow production and grazing preference. Grass and Forage Science 46: 325-331.

- \& Phillips, C.J.C. 1993. Sodium fertilizer application to pasture. 1. Direct and residual effects on pasture production and composition. Grass and Forage Science 48: 189-202.

- \& Phillips, C.J.C. 1995. Sodium in forage crops. In: Phillips, C.J.C. \& Chiy, P.C. (eds.). Sodium in Agriculture. Chalcombe Publications. Kent, UK. p. 4369.

- \& Phillips, C.J.C. 1996. Effects of sodium fertilizer on the chemical composition of grass and clover leaves, stems and interflorescences. Journal of Food Science and Agriculture 72: 501-510.

- \& Phillips, C.J.C. 1998. Sodium fertilizer application to pasture. 6 . Effects of combined applications with sulphur on herbage production and chemical composition in the season of application. Grass and Forage Science 53: 1-10.

- , Phillips, C.J.C. \& Ajele, C.L. 1994. Sodium fertilizer application to pasture. 5 . Effects on herbage digest- ibility and mineral availability in sheep. Grass and Forage Science 49: 25-33.

- , Phillips, C.J.C. \& Omed, H.M. 1993. Sodium fertilizer application to pasture. 3. Rumen dynamics. Grass and Forage Science 48: 249-259.

Cone, J.W. \& van Gelder, A.H. 1999. Influence of protein fermentation on gas production profiles. Animal Feed Science and Technology 76: 251-264.

Cushnahan, A., Gordon, F.L., Bailey, J.S. \& Mayne, C.S. 1996. A note on the effect of sodium fertilization of pasture on the performance of lactating dairy cows. Irish Journal of Agricultural and Food Research 35: 43-47.

Dijkshoorn, W. \& van Wijk, A.L. 1967. The sulphur requirements of plants as evidenced by the sulphur nitrogen ratio in the organic matter. A review of published data. Plant and Soil 26: 129-157.

Durand, M. \& Komisarczuk, S. 1988. Influence of major minerals on rumen microbiota. Journal of Nutrition 118: 249-260.

Friedel, K. 1990. Die Schatzung des energetischen Futterwertes von Grobfutter mit Hilfe einer Cellulase methode. Wissenschaftliche Zeitung Universitet Rostock, N-Reihe 39: 78-86.

Goering, H.K. \& Van Soest, P.J. 1970. Forage fiber analyses. Apparatus, reagents, procedures, and some applications. Agriculture Handbook No. 379. ARS, USDA, Washington, D.C.

Huhtanen, P. 1993. Factors influencing forage intake. In: Fredeen, A. (ed.). Proceedings of Nova Scotia forage conference forage: seeding to feeding. Nova Scotia Forage Council, Canada. p. 103-127.

- \& Kukkonen, U. 1995. Comparison of methods, markers and sampling sites and models for estimating digesta passage kinetics in cattle fed at two levels of intake. Animal Feed Science and Technology 52: 141-158.

Hungate, R.E. 1966. The rumen and it's microbes. Academic Press, New York and London.

Jones, L.H.P., Cowling, D.W. \& Lockeyr, D.R. 1972. Plant available and extractable sulphur in some soils in England and Wales. Soil Science 114: 104-114. 


\title{
Huhtanen, P. et al. Effects of sodium and potassium application on the nutritive value of timothy
}

Kähäri, J. \& Nissinen, H. 1978. The mineral element contents of timothy (Phleum pratense) in Finland: The elements of calcium, magnesium, phosphorus, potassium, chromium, cobalt, iron, manganese, sodium and zinc. Acta Agriculturae Scandinavica, Supplement 20: 26-39.

Luh Huang, C.-Y. \& Schulte, E.E. 1985. Digestion of plant tissue for analysis by 1CP emission spectrometry. Communications in Soil Science and Plant Analysis 16: 943-958.

Moseley, G. 1980. Effects of variation in herbage sodium levels and salt supplementation on the nutritive value of perennial ryegrass for sheep. Grass and Forage Science 35: 105-113.

Pell, A.N. \& Schofield, P. 1993. Compuriterized monitoring of gas production to measure forage digestion in vitro. Journal of Dairy Science 76: 1063-1073.

Peltovuori, T. \& Yli-Halla, M. 1997. Influence of sodium and potassium fertilization on the sodium concentration of timothy. Agricultural and Food Science in Finland 6: 259-268.

Pond, K.R., Ellis, W.C., Matis, J.H., Ferreiro, H.M. \& Sut- ton, J.D. 1988. Compartmental models for estimating attributes of digesta flow in cattle. British Journal of Nutrition 60: 571-595.

SAS 1985. SAS User's Guide: Statistics. 5th Ed. Statistical Analysis Systems Institute Inc., Cary, NC.

Sniffen, C.J., O'Connor, J.D., Van Soest, P.J., Fox, D.G. \& Russel, J.B. 1992. A net carbohydrate and protein system for evaluating cattle diets: II Carbohydrate and protein availability. Journal of Animal Science 70: 3562-3577.

Spears, J.W. 1994. Minerals in forages. In: Fahey, G.C., Jr. et al. (eds.). Forage Quality, Evaluation and Utilization. American Society of Agronomy, Madison. p. 281-317.

- , Burns, J.C. \& Hatch, P.A. 1985. Sulphur fertilization of cool season grasses and effect on utilisation of minerals, nitrogen and fiber by steers. Journal of Dairy Science 68: 347-355.

Van Soest, P.J., Robertson, J.B. \& Lewis, B.A. 1991. Methods for dietary fiber, neutral detergent fiber and nonstarch polysaccharides in relation to animal nutrition. Journal of Dairy Science 74: 3583-3597.

\section{SELOSTUS}

\section{Natrium- ja kaliumlannoituksen vaikutus timotein ravintoarvoon}

\author{
Pekka Huhtanen, Seppo Ahvenjärvi ja Terttu Heikkilä \\ Maatalouden tutkimuskeskus
}

Tutkimuksen tavoitteena oli selvittää natrium- ja kaliumlannoituksen vaikutusta timotein ravintoarvoon. Näytteet olivat Peltovuoren ja Yli-Hallan (1997) astiakokeesta, jossa selvitettiin Na- ja K-lannoituksen vaikutusta timotein $\mathrm{Na}, \mathrm{K}, \mathrm{Ca}$ ja $\mathrm{Mg}$-pitoisuuteen ja satoon savi-, hieta- ja turvemaalla. Käytetyt ravinnemäärät olivat 0,200 tai $400 \mathrm{mg} \mathrm{Na} \mathrm{l}^{-1}$ kokeen alussa natriumsulfaattina ja 0,100 tai $200 \mathrm{mg}$ $\mathrm{K} 1^{-1}$ joka sadolle kaliumkloridina. Tähän tutkimukseen valittiin kolmannen sadon näytteet, koska niissä Na-pitoisuuden vaihtelu oli suurin $(0,16-7,13 \mathrm{~g}$ $\left.\mathrm{kg}^{-1}\right)$. Vaikka timotei luetaan ns. natrofobisiin kasveihin, jotka ottavat huonosti natriumia versoihin, nousi timotein natriumpitoisuus huomattavasti. Na- ja K-lannoituksen vaikutusta timotein ravintoarvoon tutkittiin in vitro -kokein ja lisäksi määritettiin typpi, neutraalideterkenttikuitu (NDF), sokeri, rikki ja fosfori. Orgaanisen aineen in vitro -sulavuus määritettiin sellulaasimenetelmällä ja potentiaalinen kuiva-aineen ja NDF:n pötsisulavuus inkuboimalla näytettä 12 vrk nailonpussissa kahden lehmän pötsissä (in situ). Sulatuskinetiikan parametrit määritettiin mikrobikäymisen tuottaman kaasuntuotannon mittauksella ajan funktiona automaattisella mittauslaitteella, ja dynaamisen ja pötsimallin perusteella laskettiin potentiaalisesti sulavan kuiva-aineen pötsisulavuus ja kuivaaineen todellinen pötsisulavuus.

Lannoituksen vaikutus raakavalkuais-, NDF- ja sokeripitoisuuteen oli pieni. Na-lannoitus lisäsi hieman ja K-lannoitus vähensi typpipitoisuutta ja molemmat vähensivät laskennallista sokeripitoisuutta. NDF-pitoisuus nousi hieman Na-lannoituksella. Nalannoitus lisäsi ja K-lannoitus vähensi rikki- ja fosforipitoisuutta vaikutuksen riippuessa maalajista.

Na-lannoituksen vaikutukset orgaanisen aineen in vitro sulavuuteen sekä potentiaaliseen kuiva-aineen ja NDF:n pötsisulavuuteen olivat pieniä, vaikkakin tilastollisesti merkitseviä. Kokonaiskaasutuotanto ja nopeasti sulavan fraktion kaasutuotannon nopeus vähenivät, kun timotein typpi-, rikki-, kalsium-, mag- 
Vol. 9 (2000): 105-119.

nesium-, fosfori- ja natriumpitoisuudet nousivat. Nalannoituksella ei ollut vaikutusta sulatuskinetiikan parametreihin ja estimoituun potentiaalisesti sulavan kuiva-aineen pötsisulavuuteen tai kuiva-aineen todelliseen pötsisulavuuteen, kun taas K-lannoitus lisäsi hieman nopeasti sulavan fraktion kaasutuotannon nopeutta ja todellista kuiva-aineen pötsisulavuutta. Kaliumin vaikutus oli selvin turvemaalla. Maalajien välillä oli eroja kaasuntuotannon määrässä ja poten- tiaalisesti sulavan kuiva-aineen ja todellisessa kuivaaineen pötsisulavuudessa, savimaan ruoho oli huonoiten ja turvemaan ruoho parhaiten sulavaa. Näiden tulosten mukaan Na-lannoituksella ei näytä olevan samanlaisia myönteistä vaikutusta timotein ravintoarvoon kuin brittiläistutkimuksissa on usein esitetty englannin raiheinällä, mutta K-lannoitus voi parantaa timotein ravintoarvoa K-puutteesta kärsivillä mailla. 
AGRICULTURAL AND FOOD SCIENCE IN FINLAND 